\title{
The effect of environmental temperature on the nitrogen metabolism and growth of the young pig
}

\author{
By M. F. FULLER* \\ Department of Veterinary Clinical Studies, University of Cambridge \\ (Received 14 April 1965-Accepted 21 Fune 1965)
}

The most obvious nutritional consequence of keeping a pig in an environment below its zone of thermal neutrality is that its heat production is increased, and the extra heat is produced by the oxidation of nutrients derived originally from the diet. This accounts for the increase in the food required per unit of weight gain by pigs in the cold (Heitman \& Hughes, 1949; Sørensen, 1960). If the animal's food intake is not increased during exposure to cold, a reduction in growth rate can also be expected (Comberg, 1959; Siegl, 1960; Sørensen, 1960). If food is supplied ad lib., it may be consumed in greater quantities in the cold (Heitman \& Hughes, I949; Gill \& Thomson, 1956), but the increase may be insufficient to prevent a retardation of growth (Heitman \& Hughes, 1949).

Although the increased heat production may be derived from the oxidation of carbohydrate, fat or protein, both the overall rate of growth and the ratio of fat to lean body mass may be considerably influenced by the relative proportions of the different nutrients which are katabolized. In this regard, the most important issue is the extent to which the katabolism of amino acids is accelerated during exposure to cold. Piatkowski (1958) and Moustgaard, Nielsen \& Sørensen (1959) have reported that, when pigs were given the same amount of food at all temperatures, those in the colder environments retained appreciably less of their dietary nitrogen.

Pigs weighing up to $50 \mathrm{~kg}$ or so are commonly fed ad lib., and this experiment was designed to find out whether, during this period of the pig's life, when the influence of the physical environment is probably greatest, a low environmental temperature is associated with a decreased retention of $N$. Because the relative effect of a given environment changes as the animal grows, the effect of different temperatures was examined in successive short periods.

It was found that, under conditions of $a d$ lib. feeding, low environmental temperatures were accompanied by an apparent increase in the faecal excretion of $\mathrm{N}$ but that there was essentially no difference in the relation between urinary $\mathrm{N}$ and digested $\mathrm{N}$.

\section{EXPERIMENTAL}

Animals. Twenty-two male Landrace piglets were taken from twenty-two different litters in two minimal-disease herds. (The founder members of these herds were delivered by hysterectomy and deprived of colostrum; Betts, Lamont \& Littlewort, I960.) The piglets were taken from the sows at 3 days of age and reared on a milksubstitute diet (Amvilac no. I, Glaxo Research Ltd). They were kept at $30^{\circ} \pm 2^{\circ}$ during

* Present address: Rowett Research Institute, Bucksburn, Aberdeen. 
this period. At Io days of age they were castrated in the usual way. From the I I th to the I4th day of life, their diet was gradually changed to that which they were to eat during the experiment. The experiment began on the $5_{5}$ th day of life, when the pigs weighed, on average, $3.8 \mathrm{~kg}$.

Plan of experiment. Four pigs were kept for $5^{6}$ days at each of the temperatures $10^{\circ}, 15^{\circ}, 20^{\circ}, 25^{\circ}$ and $30^{\circ}$ (all $\pm<1^{\circ}$ ), with air movement between 4 and $5 \mathrm{~cm} / \mathrm{sec}$. In addition, two pigs were kept at $10^{\circ}$ with a higher level of air movement $(35 \mathrm{~cm} / \mathrm{sec})$; this treatment is called ' $10^{\circ}+$ '. Relative humidity was always maintained at $70 \%$ saturation. When 15 days old, each piglet was placed in a metabolism cage measuring $92 \times 92 \mathrm{~cm}$ and $6 \mathrm{I} \mathrm{cm} \mathrm{high,} \mathrm{which} \mathrm{was} \mathrm{set} \mathrm{up} \mathrm{in} \mathrm{one} \mathrm{of} \mathrm{three} \mathrm{climatic} \mathrm{chambers,} \mathrm{the}$ design of which is to be published elsewhere. The cages were made entirely of wire mesh to allow the animal no opportunity of modifying its local environment. The pigs were given both food and tap-water ad lib. Every day the uneaten food was weighed and returned to the pig with an additional weighed quantity. Each pig was weighed daily to the nearest $\frac{1}{4} \mathrm{lb}(\mathrm{I} / 3 \mathrm{~g})$. $\mathrm{N}$ balances were determined in eight successive 7 -day periods. At the end of the experiment, i.e. when they were 70 days old, all the pigs were killed and dissected.

Diet. The diet was Amvilac no. 2 (Glaxo Research Ltd), prepared from cereals, white-fish meal and dried skim milk, and was in the form of pellets. The composition is given in Table $\mathrm{x}$. Two determinations were made with each of two pigs kept at $20^{\circ}$ of the apparent digestibility of energy. The mean value was $87.6 \%$.

\section{Table I. Composition of the diet}

\begin{tabular}{lc}
\multicolumn{1}{c}{ Constituent } & $\%$ of diet \\
Moisture & $11 \cdot 5-12 \cdot 4 \dagger$ \\
$\mathrm{N} \times 6 \cdot 25$ & $22 \cdot 1-24 \cdot 0 \dagger$ \\
Light petroleum extract & $7 \cdot 5-8 \cdot 4 \dagger$ \\
Fibre & $1 \cdot 0 *$ \\
Calcium & $1 \cdot 3^{*}$ \\
Phosphorus & $1 \cdot 0^{*}$
\end{tabular}

* Data supplied by manufacturer.

$\begin{array}{lc}\text { Constituent } & \text { Per ton of diet* } \\ \text { Procaine penicillin } & 4 \circ \mathrm{g} \\ \text { Oxytetracycline } & \text { ro g } \\ \text { Riboflavine } & 8 \mathrm{~g} \\ \text { Nicotinic acid } & 50 \mathrm{~g} \\ \text { Calcium D-pantothenate } & 17 \mathrm{~g} \\ \text { Vitamin } \mathrm{B}_{12} & 30 \mathrm{mg} \\ \text { Vitamin A } & 10 \times 10^{8} \mathrm{i} . \mathrm{u} . \\ \text { Vitamin } \mathrm{D}_{3} & 2.5 \times 10^{\circ} \mathrm{i} . \mathrm{u} .\end{array}$

$\uparrow$ By analysis of each batch.

Environmental conditions. Each chamber was insulated by a $7.6 \mathrm{~cm}$ thickness of expanded polystyrene or its equivalent, giving a thermal conductance of $0.35 \mathrm{kcal} / \mathrm{m}^{2}$ per $\mathrm{h}$ per ${ }^{\circ} \mathrm{C}$. Because of this low conductance, wall temperature differed little from air temperature. Temperatures were controlled by long-stem bimetallic helix thermostats, operating through electronic relays, and were recorded continuously on a sixchannel potentiometric recorder by means of copper and constantan thermocouples with measuring junctions near to the pigs. To measure humidity, the measuring junctions of two thermocouples were inserted into a tube through which a fan could be made to draw air at a speed of $310 \mathrm{~cm} / \mathrm{sec}$. The junction nearest to the fan was covered with a cotton wick which dipped into distilled water. One of these psychrometric units was mounted in each chamber, and readings were taken at least once daily. Air movement was measured by silvered katathermometers, using the nomogram of Bedford (1946). 
Collection of excreta. About $25 \mathrm{~cm}$ below each cage floor was a shallow funnel of $0.15 \mathrm{~mm}$-thick polyvinyl chloride supported by a wooden frame. Beneath the aperture at the centre was a bottle containing $\mathrm{I} O \mathrm{ml} \mathrm{ION}-\mathrm{H}_{2} \mathrm{SO}_{4}$ into which urine was received. This bottle was changed at the same time each day and portions of the urine were taken for analysis; these were pooled during each 7 -day period. Faeces were collected daily and stored at $-25^{\circ}$ during the 7-day collection period. At the end of this time, they were thawed at $2^{\circ}$, weighed and homogenized with a known weight of water in a large top-drive blender.

Slaughter. At 70 days of age, each pig was anaesthetized with $0.3 \mathrm{mg} / \mathrm{kg}$ bodyweight of pentobarbitone sodium (Nembutal; Abbot Laboratories Ltd), injected into an ear vein. An endotracheal tube was introduced and the animal was weighed. A midline incision was made from $10 \mathrm{~cm}$ anterior to the umbilicus to $5 \mathrm{~cm}$ anterior to the pelvic brim. The aorta was exposed by blunt dissection for a length of $3 \mathrm{~cm}$ about $4 \mathrm{~cm}$ anterior to the iliac bifurcation. The distal end of this length was ligated and the proximal end clamped. A cannula was inserted and tied in place and the proximal clamp was removed. The blood was led away to a tared bottle through tubing treated with heparin. All blood shed during this and subsequent procedures was absorbed on weighed cotton-wool.

Dissection. The midline incision was extended to the pharynx and the anus. The spleen, liver, heart, alimentary tract, lungs and kidneys were removed in order, blotted free of surplus blood and weighed. The hair was removed with electric clippers and the carcass was then cooled in a polyethylene sack in a deep-freeze. The alimentary tract was emptied and reweighed. The cooled carcass was decapitated by disarticulation of the skull at the atlas vertebra and by a transverse incision in the same plane. The tail was also removed. The spine was sawn down the midline and each side of the carcass was weighed, the left side being retained for dissection. The peritoneal fat was removed first, followed by the skin and subcutaneous fat together. All exposed surfaces were covered with cold, damp towels. The muscles were freed from remaining subcutaneous fat and dissected from the bones, together with their tendons and inter-muscular fat. Major blood vessels, glands and spinal cord were classed together as 'remainder'. After they had been weighed, the visceral organs and 'remainder' were minced and homogenized together and were treated for analytical purposes as one tissue. The panniculus muscle was dissected from the subcutaneous fat, which was then separated from the skin. The head was dissected in a similar way, the skull being sawn open and the brain removed and weighed. The tongue was included with the muscle; the eyes and salivary glands with the 'remainder'.

Analytical methods. $\mathrm{N}$ was determined by Kjeldahl's method, using $\mathrm{CuSO}_{4} \cdot 5 \mathrm{H}_{2} \mathrm{O}$ and powdered $\mathrm{Se}$ as catalysts and $0.33 \mathrm{~g} \mathrm{~K}_{2} \mathrm{SO}_{4} / \mathrm{ml}_{3} 6 \mathrm{~N}-\mathrm{H}_{2} \mathrm{SO}_{4}$. Samples of the homogenized faeces were transferred by wide-bore pipette to tared digestion flasks which were then reweighed. $\mathrm{N}$ in urine was determined in duplicate, that in food and faeces in triplicate. If the variation between replicates exceeded $\mathrm{I} \%$ of their mean, the analysis was repeated. Each set of digestions (four to five samples) included a standard solution of either urea or creatinine as a check of accuracy.

The fat content of the dissected tissues was determined by extraction of the dried 
material with light petroleum (boiling range $40^{\circ}-60^{\circ}$ ) in a Soxhlet apparatus. The whole mass of each tissue was frozen, minced and thoroughly mixed by hand. A sample of about $600 \mathrm{~g}$ was withdrawn and stored in a sealed polyethylene bag at $-25^{\circ}$. Before analysis it was reweighed and then minced. About $200 \mathrm{~g}$ was dried at reduced pressure over anhydrous $\mathrm{CaCl}_{2}$ (fatty tissue was not dried before extraction). The difference between the weight of the dried extracted residue and that of the dried extract was taken to be the weight of residual water (Callow, 1947).

Energy content. The heats of combustion of the food and faeces samples were determined in a ballistic bomb calorimeter (A. Gallenkamp \& Co. Ltd, London) calibrated with thermo-chemical standard grade benzoic acid.

\section{RESULTS}

Appearance and condition of the animals. The pigs at $10^{\circ}$ were remarkable for their long, curly hair, and it was of interest to know whether there were detectable differences in the amount of hair grown by the animals at different temperatures. The weight of hair clipped off at slaughter was recorded and the results are summarized in Table 2. It may be seen that the weight of hair showed a significant tendency to increase at the lower temperatures, and this tendency is accentuated if the weights are expressed per $\mathrm{m}^{2}$ of surface area. It was also noticed that the pigs at $30^{\circ}$ had conspicuously larger ears than the others, and this was also investigated. Tracings were made of the upper surfaces of both ears after slaughter and the areas of these tracings were determined; these results are also shown in Table 2 . They confirm that the pigs at $30^{\circ}$ had significantly larger ears than the other pigs.

Table 2. Weight of the hair and area of the ears of pigs kept for 56 days at the temperatures shown

(Each value is the mean for four pigs, except where otherwise indicated)

\begin{tabular}{|c|c|c|c|c|c|c|c|c|}
\hline & $10^{\circ}+$ & $10^{\circ}$ & $15^{\circ}$ & $20^{\circ}$ & $25^{\circ}$ & $30^{\circ}$ & SEM* & $\begin{array}{c}\text { Significance } \\
\text { of differences } \\
\text { between means }\end{array}$ \\
\hline Weight of hair (g) & $42 \cdot 9 \dagger$ & $4 I \cdot 9$ & $23 \cdot 6$ & $33 \cdot 4$ & $17 \cdot 0$ & 16.4 & $\pm 3 \cdot 8$ & $P<0.01$ \\
\hline Weight of hair $\left(\mathrm{g} / \mathrm{m}^{2} \downarrow\right)$ & $49.9 \dagger$ & $47 \cdot \mathbf{r}$ & 25.5 & 33.7 & $16 \cdot 8$ & 19.0 & $\pm 3 \cdot 9$ & $P<0.00 \mathrm{x}$ \\
\hline $\begin{array}{l}\text { Area of both ears } \\
\left(\mathrm{cm}^{2}\right)\end{array}$ & $-\S$ & 244 & 223 & 261 & 264 & 294 & \pm 17 & NS \\
\hline $\begin{array}{l}\text { Area of both ears } \\
\left(\mathrm{cm}^{2} / \mathrm{m}^{2} f\right)\end{array}$ & $-\S$ & 276 & 234 & 263 & 259 & 342 & \pm 18 & $P<0.01$ \\
\hline $\begin{array}{l}\text { NS, not significant. } \\
* \text { Excluding } 10^{\circ}+ \\
+ \text { Two pigs only. } \\
\ddagger \text { Computed from } t \\
\$ \text { No measurements }\end{array}$ & DO & . & 2 & & are & $=$ & & igh \\
\hline
\end{tabular}

Pigs in the cold characteristically adopted a flexed posture with the hind legs alongside or partially beneath the body. Both pigs at $10^{\circ}+$, two at $10^{\circ}$ and one at $15^{\circ}$, after a few days of the experiment, showed difficulty in extending their hind legs normally and soon became unable to stand up. One of the pigs at $10^{\circ}$ subsequently recovered spontaneously after $3-4$ weeks. This condition has apparently not previously been described, and in order to investigate its nature, tissue samples were taken at 
slaughter from the right sides of two of the affected animals and from two normal animals (kept at $20^{\circ}$ ). Sections of the spinal cord (thoracic, lumbar and sacral), of the sciatic nerve and of the biceps femoris, semitendinosus, semimembranosus and quadriceps femoris muscles were examined histologically. In none of the sections examined was there apparent damage to the spinal cord. In the pigs with chronic leg weakness there was evidence of muscular atrophy, and in one an increase of sarcolemmal cells. The distribution of the affected fibres did not suggest previous injury to peripheral nerve. In the sciatic nerve of the other affected pig there were a few swollen basophilic fibres, of unknown significance. There was therefore no clear evidence that this condition originated from damage to nervous tissue.

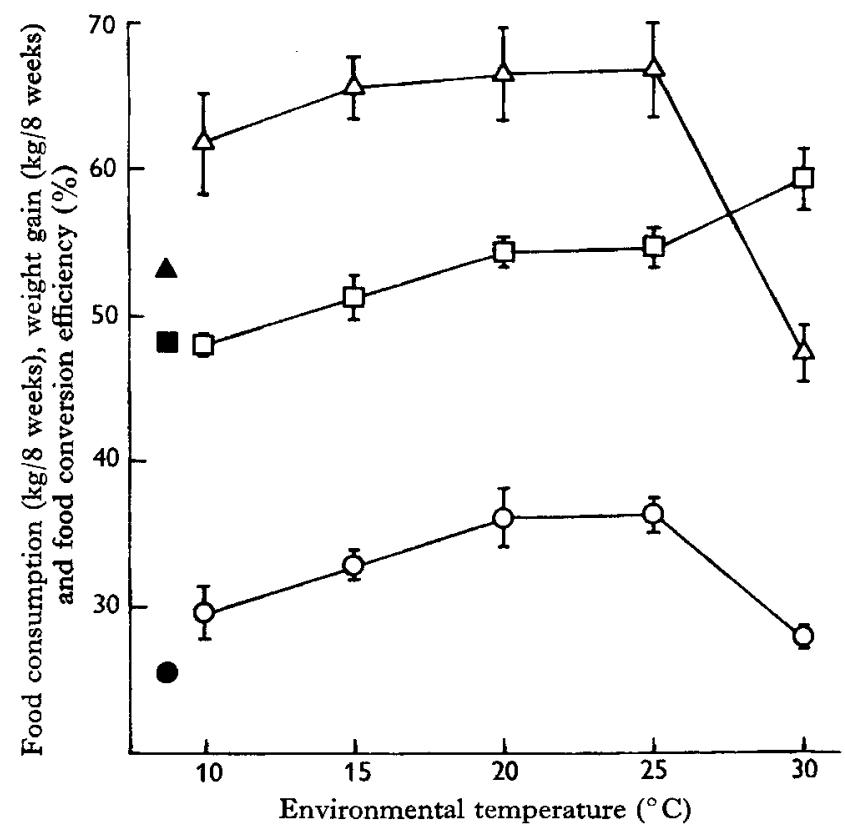

Fig. I. Total food consumption per pig $(\Delta, \Delta)$, weight gain per pig $(0, \bullet)$ and overall food conversion efficiency $(\square, \square)$ of four pigs at each temperature with low air movement (open symbols) and of two pigs at $10^{\circ}$ with high air movement (closed symbols). The values are the means with standard errors shown as vertical bars.

Food intake, growth and food conversion efficiency. The summarized values for the whole experiment are presented in Fig. I. Food intake was significantly lower at $30^{\circ}$ than at the other temperatures $(P<0.01)$. Growth rate was similar at $20^{\circ}$ and $25^{\circ}$, but was reduced at lower temperatures. At $30^{\circ}$ it was lower than at $10^{\circ}$, by virtue of the greatly reduced food intake, in spite of a systematic improvement of food conversion efficiency with increasing temperature. The variance ratios were all significant at $P<0.0$, that for food conversion efficiency at $P<0.001$.

Food intake in relation to body-weight. To examine the effect of temperature on food consumption at any given body-weight, the regressions of log food intake on log body-weight were calculated. They are presented in Table 3 , and the curves they describe may be compared directly in Fig. 2. There were no significant differences between the exponents of body-weight at the different temperatures, and the pooled 
value, excluding pigs at $10^{\circ}+$, was 0.72 . Food consumption has therefore been expressed per $\mathrm{kg}^{0.72} /$ week, and these values are also given in Table 3 . Food intake was increased by $12 \pm 2 \mathrm{~g} / \mathrm{kg}^{0.72}$ week for each $\mathrm{I}^{\circ}$ fall of temperature, and this trend was highly significant $(P<0.001)$. The unexpectedly low food consumption of the pigs at $10^{\circ}+$ was probably due to the leg weakness suffered by these animals, for it was noted that the pigs with leg weakness at $10^{\circ}$ or $15^{\circ}$ also ate less than the others of their groups (see appendix).

$N$ metabolism. The basic values for $\mathrm{N}$ metabolism are provided in the appendix, but the main results are summarized in the following paragraphs.

Excretion of $N$ in the faeces. The percentage of the total 8-week $\mathrm{N}$ intake appearing in the faeces was found to be increased significantly with a reduction of environmental temperature. Also, the regression equations relating faecal $\mathrm{N}$ to $\mathrm{N}$ intake were Table 3. Regressions of $y$ (food consumption in $\mathrm{kg} /$ week) on $x$ (mean body-weight in kg)

(The mean exponent of body-weight being $0.72 t$, the quantities of food consumed by each group of pigs per $\mathrm{kg}^{0.72}$ are also given)

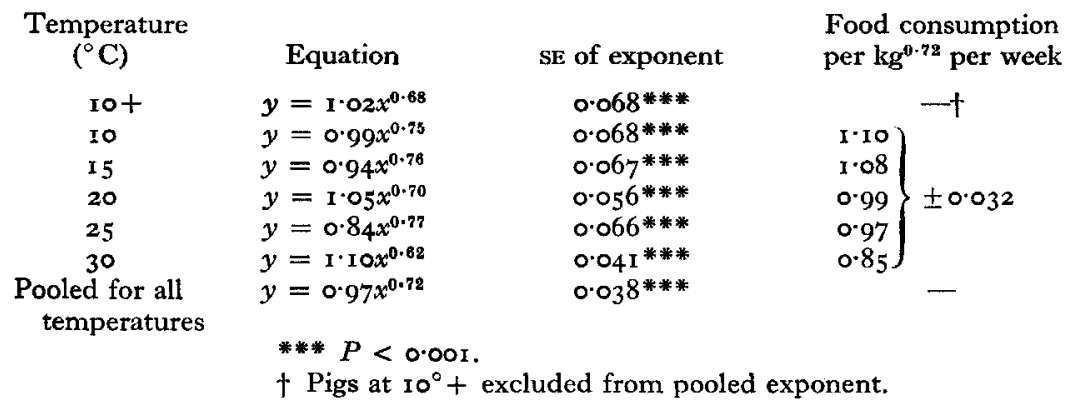

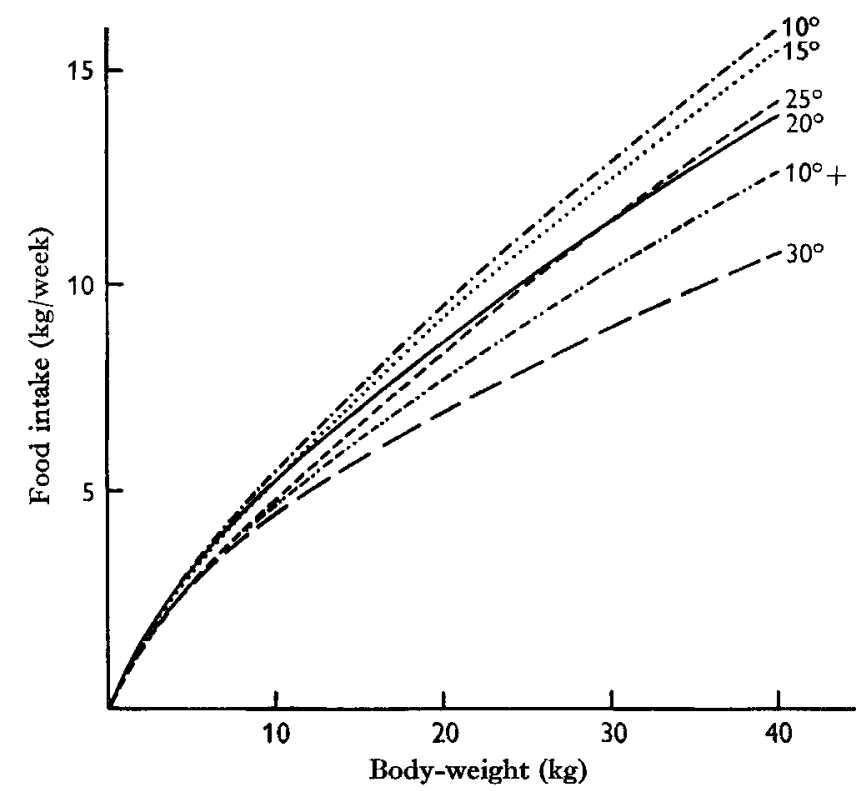

Fig. 2. Relation between food consumption and body-weight of pigs at each of the temperatures shown. 
calculated, and the regression coefficients were found to increase significantly at low temperatures. These results are presented in Table 4.

Excretion of $N$ in the urine. The results indicated that the urinary excretion of digested $\mathrm{N}$ was slightly but not significantly increased in the cold environments. The regression equations relating $\log$ urinary $\mathrm{N}$ excretion to $\log \mathrm{N}$ intake were calculated and the regression lines may be compared directly in Fig. 3. It will be seen that during

\section{Table 4. Summarized values for $N$ metabolism}

(The values are means for four pigs at each temperature, except at $10^{\circ}+$, at which there were only two)

Faecal N

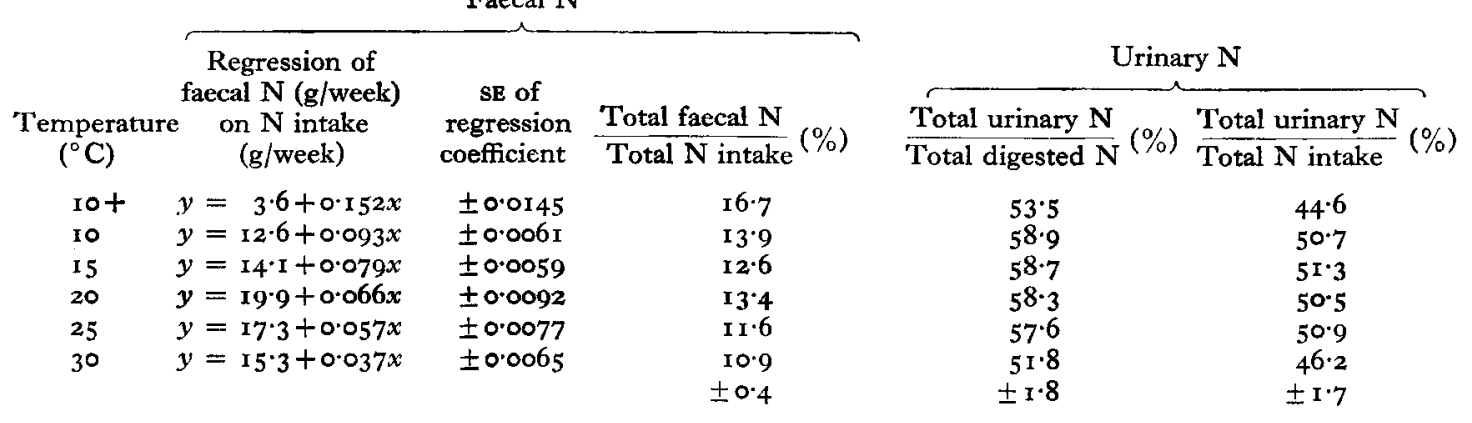

Significance of differences between means

- $\quad$ - $\quad P<0.001 \quad$ NS

Significance of differences between regression coefficients

$P<0.001$

NS, not significant.

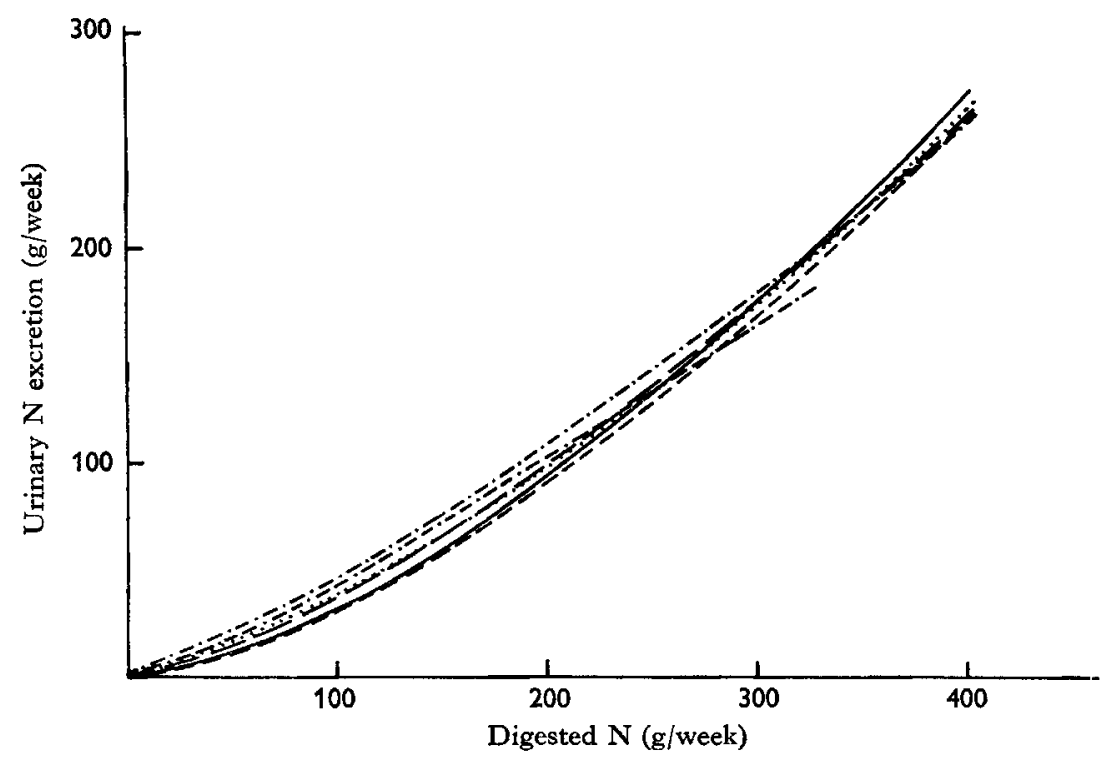

Fig. 3. Relation between urinary nitrogen excretion and digested nitrogen shown by pigs at various temperatures. $-\cdot-\cdot 10^{\circ} ;--\cdot-, 10^{\circ}+; \cdots, 15^{\circ} ;-, 20^{\circ} ;----, 25^{\circ} ;-\cdots$, $30^{\circ}$. 
the early part of the experiment pigs at $10^{\circ}$ and at $10^{\circ}+$ excreted slightly more $\mathrm{N}$ than the other pigs, but that this effect did not persist. At no value of digested $\mathrm{N}$ were there significant differences between the estimates of the amounts of $\mathrm{N}$ excreted at different temperatures. Over the whole experiment, the percentage of the digested $\mathrm{N}$ appearing in the urine increased by $1.3 \%$ between $25^{\circ}$ and $10^{\circ}$ : these results are summarized in Table 4 . At $10^{\circ}+$ and particularly at $30^{\circ}$ this percentage was lower, which is probably explained by the much lower food intakes of these animals (see Figs. I and 2), for the slope of the line relating urinary $N$ to digested $N$ increased at higher values of digested $\mathrm{N}$, and the pigs at $30^{\circ}$ and $10^{\circ}+$, with their lower food intakes, are represented only on the lower part of this curve, where $\mathrm{N}$ excretion is proportionately less.

\section{Table 5. Weights $(\mathrm{kg})$ of the organs and tissues of pigs kept for $5^{6}$ days at the temperatures shown}

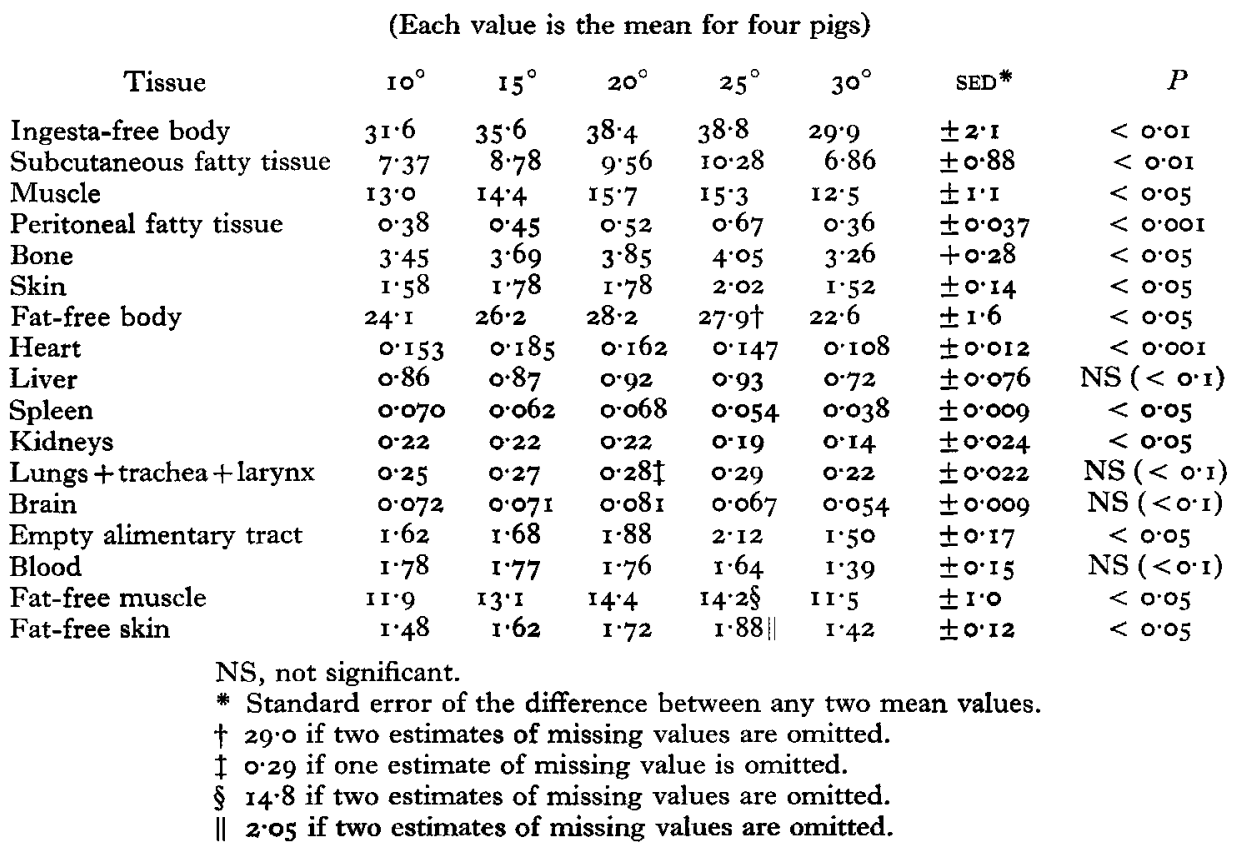

Body composition. The mean weights of the principal tissues, both intact and fatfree, and of the major organs are given in Table 5. Most of the differences between temperatures were related to differences in the body-weights at different temperatures, and covariance analyses were made to adjust for these differences. Two values of fatfree body-weight were missing but to facilitate the covariance analysis were estimated with a standard error of $\pm 0.4 \mathrm{~kg}$ from the regression of total fat on ingesta-free body weight. Those adjusted values that showed a significant effect of environmental temperature are presented in Table 6.

Fat content of the dissected tissues. The quantities of light petroleum-extracted fat in each of the tissues showed considerable variation at any one temperature and analysis of variance showed no significant differences due to temperature. It was of interest 


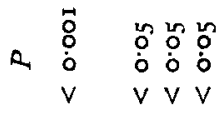

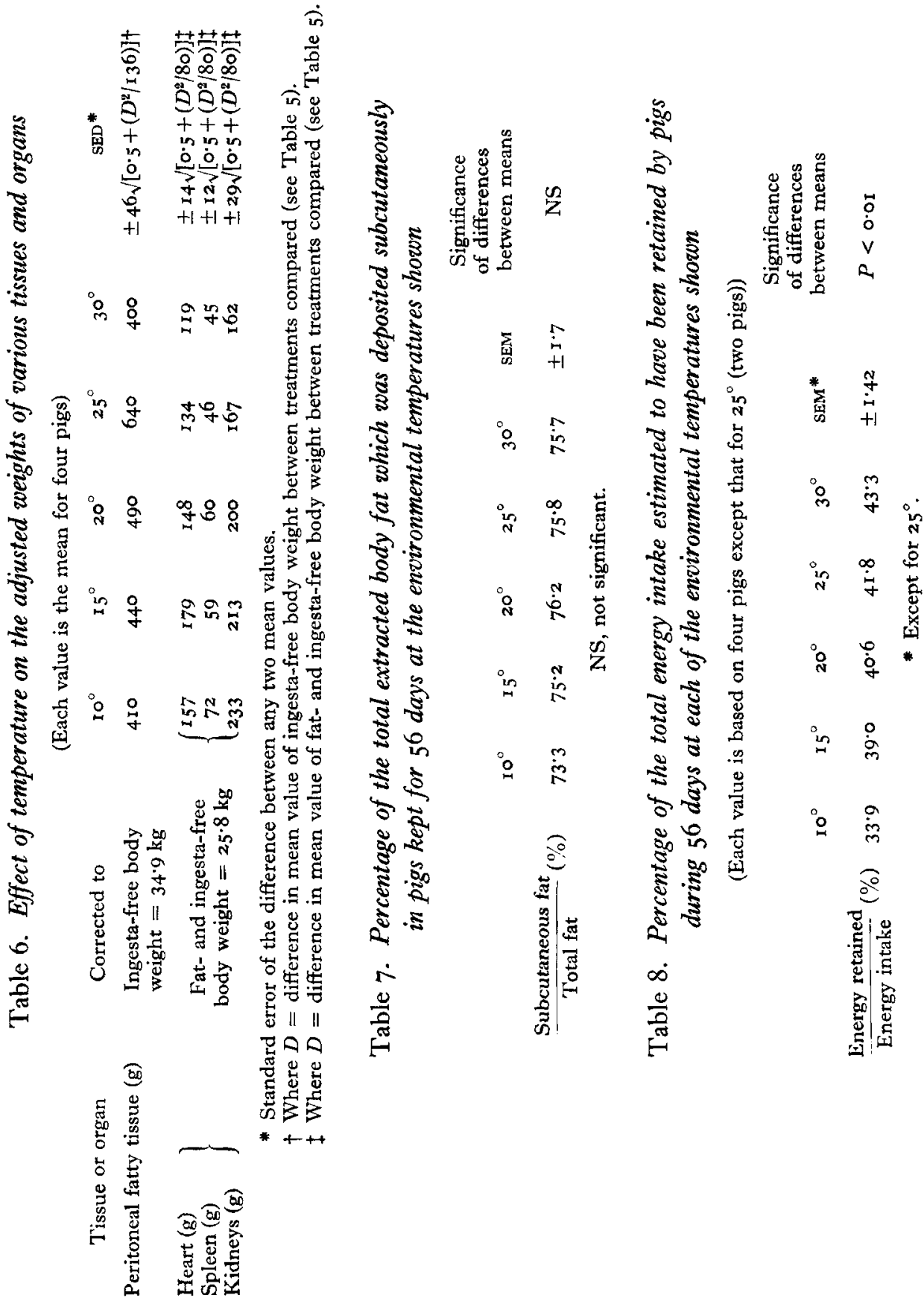

Nutr. 19,4 
to know whether pigs in the cold deposited more of their total body fat subcutaneously than pigs at the higher temperatures. The values in Table 7 show that they did not.

Energy retention. This experiment involved the assumption that the proportion of the energy intake retained by the pigs would be reduced at low environmental temperatures. To assess this effect, the values for $\mathrm{N}$ retention and body fat content were used to form an estimate of energy retention. The fat content of the pigs at the beginning of the experiment, when they weighed, on average, $3.8 \mathrm{~kg}$, was taken to be $10 \%$ (Manners \& $\mathrm{McC}$ rea, 1963 ). An error of $\mathrm{I} \%$ in this estimate makes a difference of only $38 \mathrm{~g}$ in a total quantity of about $8000 \mathrm{~g}$ of fat, and is unlikely to invalidate the comparison of the effects of temperature. The factors used to convert $\mathrm{N}$ retention and fat deposition into calories were based on the analyses by Franke \& Weniger (1958) of tissues from pigs of a similar weight. These authors reported that the fat- and ashfree dry matter of pig muscles contained $16.0 \% \mathrm{~N}$ and had a heat of combustion of $5.67 \mathrm{kcal} / \mathrm{g}$. This value takes into account the glycogen contained in the muscles. Dried, ether-extracted fat had a heat of combustion of $9.46 \mathrm{kcal} / \mathrm{g}$. From Table 8 it may be seen that the percentage of the energy intake retained fell by $4.3 \%$ between $30^{\circ}$ and $15^{\circ}$ and by a further $5.1 \%$ between $15^{\circ}$ and $10^{\circ}$.

The results given above were based on only four pigs per treatment and any conclusions must accordingly be tentative; nevertheless, the statistical significance of certain trends has been established and these will now be discussed.

\section{DISCUSSION}

The extent to which the katabolism of amino acids is accelerated during cold exposure probably depends on the difference between the animal's intake of nonprotein calories and its thermoregulatory heat production, that is, the difference between its total heat production in the cold and that which obtains when the animal eats the same amount of food in a thermoneutral environment. If the decrease in energy retention between $30^{\circ}$ and $10^{\circ}$ can be taken as a measure of the increased heat production over this temperature range, it is clear that amino acids contributed only a small part of the food energy used in thermoregulatory heat production. It seems likely therefore that when eating ad lib., the young pig consumes enough food for protein metabolism to be unaffected by temperatures down to $10^{\circ}$, even when the diet contains $22 \%$ of protein.

The apparent increase in the faecal excretion of $\mathrm{N}$ with decreasing temperature was unexpected. No such effect was noted by Piatkowski (1958), working with pigs of 70-90 kg. An increase in the faecal energy excretion of sheep in the cold has been noted by Graham, Wainman, Blaxter \& Armstrong (1959) and by Graham (1964). These authors suggest that increased decomposition of the voided faeces in a warm environment might be responsible for this effect: the same may well apply to my results, and experiments are now in progress to examine this possibility.

The accelerated growth of hair of pigs at $10^{\circ}$ and $10^{\circ}+$ suggests an insulative adaptation to cold, such as is common in large mammals (Hart, 1957). Berry \& Shanklin (1961) showed that the overall thermal insulation of calves increased directly 
with the weight of hair per unit of surface area. On the other hand, Mount (1964) has demonstrated that shaving the hair from pigs more than a few days old does not significantly decrease their insulation, which finding he attributes to the preponderant insulative role of subcutaneous fat. It therefore seems probable that the increased hair growth did not increase the overall insulation of the pigs to an extent that was physiologically important.

In hot environments, the pig is stressed by ambient temperatures considerably lower than its body temperature (Robinson \& Lee, 1941), which stems from its poor ability to increase its evaporative heat loss (Mount, 1962). It is to be expected, therefore, that those areas of the pig's surface with little subcutaneous fat and extensive vascularization have a special role in heat dissipation. The increased area of the ears at $30^{\circ}$ may represent an adaptive response of some value to the animal. Sundstroem (1922) found that the ears of mice in a hot environment were greater in area than those of controls. The mechanism of this response perhaps lies in the differences in blood flow through the ear under different environmental conditions: Héroux (I960) noted that the mitotic rate in the epidermis of the cold-exposed rat fell with decreasing surface temperature.

One of the most important ways in which animals adapt to chronic cold exposure is by increasing their consumption of food. When food intake was expressed as a function of body-weight, it was seen that, in general, the pigs in the experiment now described behaved typically in this respect. The extra food consumed in the cold was used with reduced efficiency for growth, which was slower at $10^{\circ}$ than at $20^{\circ}$ and $25^{\circ}$. These results corroborate those of Heitman \& Hughes (1949). The pigs at $10^{\circ}+$ ate less food than all the other pigs except those at $30^{\circ}$, although they presumably suffered the highest rate of heat loss; as previously mentioned this can probably be attributed to their leg weakness.

The increased weights of the heart, spleen and kidneys of animals in the cold have been described many times in the literature, most frequently in work with small laboratory animals. MacKay, MacKay \& Addis (1928) found that the weight of the rat's kidneys increased directly with the amount of protein consumed by the animal. Since the intake of food, and therefore of protein, per unit of body-weight by the pigs in my experiment was greater, the lower the temperature, the increased weights of the kidneys may simply reflect the pigs' increased consumption of protein.

\section{SUMMARY}

I. Experiments were conducted to assess the effect of environmental temperature on the food intake, growth, nitrogen metabolism and body composition of pigs from 2 to 10 weeks of age.

2. Four castrated male Landrace pigs were kept at each of the temperatures $10^{\circ}$, $15^{\circ}, 20^{\circ} 25^{\circ}$ and $30^{\circ}$ with air movement of $4-5 \mathrm{~cm} / \mathrm{sec}$. Two further pigs were kept at $10^{\circ}$ with an air velocity of $35 \mathrm{~cm} / \mathrm{sec}\left(10^{\circ}+\right)$. Relative humidity was always maintained at $70 \%$ saturation. A pelleted diet was given, which contained, on a dry-matter basis, $25 \%$ of protein. 
3. Food consumption over the whole experiment was greatest at $25^{\circ}$ but, expressed as a function of body-weight, it was highest at $10^{\circ}$ and fell with increasing temperature. Pigs at $30^{\circ}$ ate particularly little food.

4. Growth was most rapid at $20^{\circ}$ and $25^{\circ}$. It was moderately reduced in the cold, more reduced at $30^{\circ}$ and further still at $10^{\circ}+$.

5. Food utilization efficiency increased significantly with environmental temperature $(P<0.001)$

6. There was an apparent increase in the cold in the excretion of $\mathrm{N}$ in the faeces $(P<0.001)$.

7. At the beginning of the experiment the urinary loss of digested $\mathrm{N}$ was slightly increased at $10^{\circ}$ and $10^{\circ}+$. Over the whole experiment there was an increase of $\mathrm{I} 3 \%$ between $25^{\circ}$ and $10^{\circ}$, but pigs at $30^{\circ}$ and $10^{\circ}+$ excreted in their urine rather less of the $\mathrm{N}$ they digested by virtue of their smaller food intakes.

8. Pigs at $10^{\circ}$ and $10^{\circ}+$ had more hair than those in warmer environments. Those at $30^{\circ}$ had larger ears than those at lower temperatures.

9. Some pigs in the cold suffered from failure of the extensor muscles of the hind legs. This was probably not due to nerve damage.

Io. When the weights of the various tissues and organs were corrected for differences in the animals' body-weights, only the weights of peritoneal fatty tissue, heart, spleen and kidneys were significantly affected by temperature.

I I. The percentage of the energy intake estimated to have been retained rose from $33.9 \%$ at $10^{\circ}$ to $43.3 \%$ at $30^{\circ}$.

I express particular thanks to Dr D. W. B. Sainsbury for his help and encouragement. I am indebted to the Pig Industry Development Authority for a scholarship and to DrW. F. J. Cuthbertson of Glaxo Research Ltd for the values given in Table I. I am grateful to Miss C. Jones for excellent technical assistance, to Dr A. C. Palmer for the histological examinations, to $\mathrm{Dr}$ I. F. Purchase and $\mathrm{Mr} \mathrm{L}$. Cobb, who anaesthetized the pigs and inserted the cannulas, and to Dr R. C. Campbell, Miss S. Armitage and Mr I. McDonald for the statistical analysis.

\section{REFERENCES}

Bedford, T. (1946). M.R.C. War Memor, no. I7.

Berry, I. L. \& Shanklin, M. D. (196I). Res. Bull. Mo. agric. Exp. Stn no. 802.

Betts, A. O., Lamont, P. H. \& Littlewort, M. C. G. (1960). Vet. Rec. 72, 46r.

Brody, S. (1945). Bioenergetics and Growth. New York: Reinhold Publishing Corp.

Callow, E. H. (1947). F. agric. Sci., Camb., 37, 113 .

Comberg, G. (1959). Züchtungskunde, 31, 462.

Franke, E.-R. \& Weniger, J. H. (1958). Arch. Tierernähr. 8, 81.

Gill, J. C. \& Thomson, W. (1956). F. agric. Sci., Camb., 47, 324

Graham, N. McC. (1964). Aust. F. agric. Res. I5, I I3.

Graham, N. McC., Wainman, F. W., Blaxter, K. L. \& Armstrong, D. G. (1959). J. agric. Sci., Camb., $52,13$.

Hart, J. S. (1957). Revue can. Biol. 16, 133.

Heitman, H. Jr. \& Hughes, E. H. (1949). F. Anim. Sci. 8, I7ı.

Héroux, O. ( 1960). Can. F. Biochem. Physiol. 38, 135.

MacKay, E. M., MacKay, L. L. \& Addis, T. (1928). Am. Y. Physiol. 86, 459.

Manners, M. J. \& McCrea, M. R. (1963). Br. F. Nutr. I7, 495.

Mount, L. E. (1962). F. Physiol., Lond., 164, 274.

Mount, L. E. (1964). F. Physiol., Lond., r7o, 286. 
Moustgaard, J., Nielsen, P. B. \& Sørensen, P. H. (1959). Arsberetn. Inst. Sterilitetsforskning, 2, 173. Piatkowski, B. (1958). Arch Tierernähr. 8, 16r.

Robinson, K. W. \& Lee, D. H. K. (194I). Proc. R. Soc. Qd, 53, 145.

Sieg1, O. (1960). Arch. Tierz. 3, 188.

Sørensen, P. H. (1960). TagBer. dt. Akad. LandwWiss. Berl. 23, 97.

Sundstroem, E. S. (1922). Am. F. Physiol. 60, $4^{16}$.

\section{APPENDIX}

Individual values for gain in weight and nitrogen metabolism of the pigs

(Asterisk denotes pig with leg weakness)

\begin{tabular}{|c|c|c|c|c|c|c|c|}
\hline Week & $\begin{array}{c}\text { Mean } \\
\text { body-weight } \\
(\mathrm{kg})\end{array}$ & $\begin{array}{c}\text { Food con- } \\
\text { sumption } \\
(\mathrm{kg} / \text { week) }\end{array}$ & $\begin{array}{l}\text { Weight } \\
\text { gain } \\
\text { (kg/week) }\end{array}$ & $\begin{array}{c}\mathrm{N} \\
\text { intake } \\
\text { (g/week) }\end{array}$ & $\begin{array}{c}\text { Faecal } \\
\mathrm{N} \\
\text { (g/week) }\end{array}$ & $\begin{array}{l}\text { Urinary } \\
\mathrm{N} \\
\text { (g/week) }\end{array}$ & $\begin{array}{c}\mathrm{N} \\
\text { balance } \\
\text { (g/week) }\end{array}$ \\
\hline \multicolumn{8}{|c|}{ Pigs at $10^{\circ}+$} \\
\hline $\mathbf{I}$ & $5 \cdot 75$ & $2 \cdot 94$ & $2 \cdot 15$ & $107 \cdot 6$ & $20 \cdot 5$ & $3^{6 \cdot 8}$ & $50 \cdot 3$ \\
\hline 2 & 8.01 & 3.97 & $2 \cdot 27$ & $145^{*} 3$ & $23 \cdot 8$ & $49^{\circ} 2$ & $72 \cdot 3$ \\
\hline 3 & 10.09 & $4 \cdot 13$ & $1 \cdot 25$ & $15 x \cdot 2$ & $23 \cdot 8$ & $67 \cdot 7$ & 59.7 \\
\hline 4 & I $2 \cdot 37$ & $6 \cdot 14$ & 3.97 & $224^{\circ} 7$ & $33 \cdot 4$ & $102: 4$ & $88 \cdot 9$ \\
\hline 5 & $16 \cdot 27$ & $6 \cdot 4^{6}$ & $3 \cdot 63$ & $236 \cdot 5$ & $34 \cdot 3$ & $109^{\circ} 2$ & 93.0 \\
\hline 6 & 19.77 & $8 \cdot 23$ & $4 \cdot 20$ & $301^{-1}$ & $54 \cdot 7$ & $151 \% 4$ & $95^{\circ} \circ$ \\
\hline 7 & 23.74 & $9 \cdot 26$ & $3 \cdot 51$ & $339^{\circ} 0$ & $57 \cdot x$ & $132: 1$ & $149 \cdot 8$ \\
\hline 8 & $26 \cdot 58$ & $7 \cdot 62$ & 2.95 & $278 \cdot 8$ & $42 \cdot 0$ & $135 \cdot 3$ & $101 \cdot 5$ \\
\hline \multicolumn{8}{|c|}{ Pig ro $+\mathrm{B}^{*}$} \\
\hline I & $5 \cdot 76$ & $3 \cdot 28$ & $2 \cdot 86$ & 120.4 & $32 \cdot 3$ & $4 I \cdot x$ & $47 \cdot 0$ \\
\hline 2 & $8 \cdot 36$ & $4 \cdot 83$ & $2 \cdot 6 I$ & $176 \cdot 7$ & $32 \cdot 4$ & $77 \cdot 6$ & 66 \\
\hline 3 & $11 \cdot 3^{8}$ & $6 \cdot 4 I$ & $3 \cdot 29$ & $234^{\circ} 7$ & $3^{8 \cdot 1}$ & $133^{-2}$ & $63 \cdot 4$ \\
\hline 4 & $14 * 45$ & 6.79 & $3 \cdot 18$ & $248 \cdot 4$ & $39 \cdot 7$ & I I $2 \cdot 1$ & $96 \cdot 6$ \\
\hline 5 & 17.93 & $7 \cdot 82$ & 3.40 & $286 \cdot I$ & $48 \cdot 4$ & I $66 \cdot 0$ & $71 \cdot 7$ \\
\hline 6 & $22 \cdot 03$ & 8.46 & $4 \cdot 87$ & $309 \cdot 8$ & $49^{\circ} \mathrm{I}$ & IOI'O & 159.7 \\
\hline 7 & $26 \cdot 17$ & 9.06 & $3 \cdot 86$ & $331 \cdot 9$ & $48 \cdot 2$ & 125.8 & $\begin{array}{r}57^{\circ} \\
\end{array}$ \\
\hline 8 & 30.40 & $10.8 \mathrm{I}$ & 3.06 & 396.0 & $71 \cdot 3$ & I 96.0 & $128 \cdot 7$ \\
\hline
\end{tabular}

Pig 1OA*

\begin{tabular}{|c|c|c|c|c|c|c|c|}
\hline I & 4.83 & $2 \cdot 76$ & 2.26 & $07 \cdot 2$ & $23 \cdot 3$ & & 5 \\
\hline 2 & 6.72 & $3 \cdot 51$ & $1 \cdot 70$ & 126.0 & $\begin{array}{r}235 \\
20.9\end{array}$ & $56 \cdot 4$ & $48 \cdot 7$ \\
\hline 3 & $8 \cdot 76$ & 5.60 & $2 \cdot 95$ & $197: 5$ & $26 \cdot 7$ & $(107.01)$ & $(63.8+)$ \\
\hline 4 & I I' 92 & $5 \cdot 86$ & $2 \cdot 84$ & 210.4 & $28 \cdot 4$ & $131^{\circ} 0$ & $5 I^{\circ} \mathrm{O}$ \\
\hline 5 & I 5.44 & $7 \cdot 99$ & $3 \cdot 97$ & $286 \cdot 9$ & $40 \cdot 7$ & $146 \cdot 3$ & $99^{\circ} 9^{\prime}$ \\
\hline 6 & 19.33 & 9.05 & $4 \cdot 53$ & $324 \cdot 8$ & 40.4 & 180.0 & 104.5 \\
\hline 7 & $23 \cdot 56$ & $8 \cdot 82$ & 3.75 & 316.5 & 40.3 & $179 \cdot 4$ & 96.8 \\
\hline 8 & $27 \cdot 44$ & $I I \cdot I 2$ & $3 \cdot 85$ & $399^{\circ} \mathbf{I}$ & $46 \cdot 5$ & 253.5 & $99^{\prime \prime} \mathbf{I}$ \\
\hline Pig 1 & & & & & & & \\
\hline I & $4 \cdot 8 \mathrm{I}$ & $2 \cdot 98$ & $2 \cdot 27$ & $107^{\circ} 0$ & $23 \cdot 4$ & $3^{6 \cdot 7}$ & $46 \cdot 9$ \\
\hline 2 & $7 \cdot 67$ & $5 \cdot 54$ & 3.06 & I 99.0 & $32 \cdot 7$ & $68 \cdot 9$ & $97 \cdot 4$ \\
\hline 3 & 10.89 & $6 \cdot 15$ & 3.06 & $220 \cdot 6$ & $40 \cdot 6$ & $93^{\circ} 0$ & $87 \cdot 0$ \\
\hline 4 & 14.05 & $7 \cdot 00$ & 3.06 & $25 I \cdot 2$ & $4 I \cdot 2$ & $123 \cdot 8$ & $86 \cdot 2$ \\
\hline 5 & I9. I 8 & $12 \cdot 18$ & $6 \cdot 8 \mathrm{r}$ & $437^{\prime 2}$ & $6 r \cdot 9$ & 219.4 & I $55^{\circ} 9$ \\
\hline 6 & $25 \cdot 08$ & $12 \cdot 66$ & 5.55 & $454 \cdot 4$ & $57 \cdot 6$ & 189.5 & $207 \cdot 3$ \\
\hline 7 & 30.01 & $11 \cdot 96$ & $4 \cdot 54$ & $429 \cdot 2$ & $48 \cdot 1$ & $266 \cdot 9$ & 114.2 \\
\hline 8 & $35 \cdot 36$ & $12 \cdot 60$ & $5^{\cdot 13}$ & $43^{8} \cdot I$ & $57 \cdot 0$ & $228 \cdot 2$ & I 52.9 \\
\hline Pig & & & & & & & \\
\hline I & $4 \cdot 28$ & $3 \cdot 06$ & I.93 & 105.9 & $26 \cdot 1$ & 29.0 & $50 \cdot 8$ \\
\hline 2 & $6 \cdot 79$ & $4 \cdot 97$ & $2 \cdot 94$ & IフI・ク & $36 \cdot 8$ & $58 \cdot 5$ & $76 \cdot 4$ \\
\hline 3 & $9 \cdot 63$ & $5 \cdot 65$ & 3.07 & $195 * 2$ & 27.9 & $77 \cdot 4$ & 89.9 \\
\hline 4 & 13.31 & $7 \cdot 57$ & $3 \cdot 74$ & $26 I \cdot 7$ & $37 \cdot 1$ & I I $5^{\circ} \circ$ & $109 \cdot 6$ \\
\hline 5 & $17 \cdot 35$ & 9.01 & $4 \cdot 53$ & $3 I I \cdot 4$ & $4 I \cdot 3$ & $159 \cdot 8$ & IIO. 3 \\
\hline 6 & $22 \cdot 08$ & 10.29 & $4 \cdot 88$ & $355 \cdot 7$ & $43 \cdot 6$ & $180^{\circ} 0$ & I $32 \cdot I$ \\
\hline 7 & $25 \cdot 67$ & $9 \cdot 74$ & $4^{\cdot 20}$ & $336 \cdot 6$ & $47^{\circ} 2$ & I 88.8 & I 00.6 \\
\hline 8 & 30.99 & $12 \cdot 73$ & $5 \cdot 16$ & 440.1 & 50.1 & $28_{3} \cdot 8$ & $106 \cdot 2$ \\
\hline
\end{tabular}


Mean Food con- Weight $N$ Faecal Urinary N body-weight sumption gain intake $N \quad N$ balance

Week (kg) (kg/week) (kg/week) (g/week) (g/week) (g/week) (g/week)

Pig Io D*

\begin{tabular}{|c|c|c|c|c|c|c|c|}
\hline I & $3 \cdot 45$ & 1.90 & $1 \cdot 36$ & $65 \cdot 5$ & $14 \cdot 8$ & $28 \cdot 9$ & $2 I \cdot 8$ \\
\hline 2 & $5 \cdot 51$ & $3 \cdot 98$ & $2 \cdot 3^{8}$ & I 37.8 & $24 \cdot 4$ & $45 \cdot 4$ & $68 \cdot 0$ \\
\hline 3 & $7 \cdot 94$ & 5.08 & $2 \cdot 27$ & $175 \cdot 7$ & $26 \cdot 4$ & 80.5 & $68 \cdot 8$ \\
\hline 4 & I0.74 & $6 \cdot 40$ & $3 \cdot 29$ & $221 \cdot 4$ & 29.8 & I I $5 \cdot 3$ & $76 \cdot 3$ \\
\hline 5 & $14 * 59$ & $7 \cdot 95$ & $3 \cdot 97$ & $274^{\circ} 9$ & $3^{6 \cdot 6}$ & 146.9 & $9 I \cdot 4$ \\
\hline 6 & $18 \cdot 40$ & $9 \cdot 12$ & $4 \cdot 42$ & $3 \times 5 \cdot 2$ & $45 \cdot 3$ & $I 6 I \cdot 2$ & 108.7 \\
\hline 7 & $23 \cdot 71$ & I2:I 8 & 6.01 & $42 I \cdot I$ & $5 I \cdot 8$ & $167 \cdot 2$ & $202 \cdot I$ \\
\hline 8 & $28 \cdot 74$ & 12.00 & 4.02 & $414 \cdot 9$ & $43 \cdot 9$ & 254.7 & I $16 \cdot 3$ \\
\hline
\end{tabular}

Pig $I_{5} \mathrm{~A}$

Pigs at $5^{\circ}$

\begin{tabular}{|c|c|c|c|c|c|c|c|}
\hline \multirow{2}{*}{\multicolumn{8}{|c|}{$2 \cdot 85$}} \\
\hline & $4 \cdot 31$ & $2 \cdot 85$ & $2 \cdot 27$ & 109.5 & $3 I \cdot 5$ & $28 \cdot 1$ & $49 \cdot 9$ \\
\hline 2 & $6 \cdot 97$ & $4 \cdot 87$ & $2 \cdot 94$ & I 87.5 & $3^{8 \cdot 7}$ & $66 \cdot 6$ & \\
\hline 3 & 10.31 & $6 \cdot 28$ & 3.75 & $24 I^{\prime} 5$ & $35 \cdot 5$ & IIO.O & \\
\hline 4 & 14.60 & $8 \cdot 11$ & $4 \cdot 76$ & 3120 & 39.4 & $95 \cdot 8$ & $176 \cdot 8$ \\
\hline 5 & 19.02 & $9 \cdot 26$ & $3 \cdot 97$ & 355.5 & $4 I \cdot 0$ & $202 \cdot 0$ & I 2.5 \\
\hline 6 & $24 \cdot 07$ & $12 \cdot 13$ & $6 \cdot 35$ & $464 \cdot 6$ & $48 \cdot 8$ & $270 \cdot 2$ & $145 \cdot 6$ \\
\hline 7 & $30 \cdot 58$ & 14.27 & $6 \cdot 24$ & $547 \cdot 8$ & $60 \cdot 9$ & $345^{\circ} 2$ & $\mathrm{I} 4 \mathrm{I} \cdot 7$ \\
\hline 8 & 36.07 & $12 \cdot 63$ & 4.53 & $484 \cdot 9$ & $56 \cdot 5$ & 300.0 & $128 \cdot 4$ \\
\hline \multicolumn{8}{|c|}{$\operatorname{Pig}_{15} \mathrm{~B}$} \\
\hline I & $5 \cdot 26$ & $x \cdot 96$ & $I \cdot 13$ & $75 \cdot 2$ & I5.I & 35.4 & 24.7 \\
\hline 2 & 8.08 & 5.29 & $3 \cdot 86$ & $186 \cdot 7$ & 30.7 & $65 \cdot 3$ & 90.7 \\
\hline 3 & I I 69 & 6.40 & 3.74 & $226 \cdot 0$ & 30.2 & $102 \cdot 0$ & 93.8 \\
\hline 4 & 15.73 & 6.82 & $3 \cdot 89$ & 240.7 & $31 \cdot 4$ & 109.4 & $99 \cdot 9$ \\
\hline 5 & $20 \cdot 14$ & $9 \cdot 02$ & $5 \cdot 40$ & $318 \cdot 4$ & $3^{8} \cdot 3$ & I 50.7 & I 29.4 \\
\hline 6 & 25.15 & 10.52 & $5 \cdot 00$ & $37 \times \cdot 5$ & $44 \cdot 9$ & $197 \cdot 7$ & I $28 \cdot 9$ \\
\hline 7 & $30 \cdot 38$ & I I 42 & $5 \cdot 27$ & $403 \cdot 2$ & $47 \cdot 6$ & $240 \cdot 2$ & I 15.4 \\
\hline 8 & $35 \cdot 87$ & $12 \cdot 22$ & 4.93 & $431-2$ & $5 \mathrm{I} \cdot 8$ & $260 \cdot 8$ & 118.6 \\
\hline \multicolumn{8}{|c|}{ Pig $x_{5} \mathrm{C}^{*}$} \\
\hline $\mathbf{I}$ & $4 \cdot 25$ & $2 \cdot 67$ & $2 \cdot 38$ & $94 \cdot 4$ & $18 \cdot 8$ & $28 \cdot 6$ & $47 \cdot 0$ \\
\hline 2 & $6 \cdot 90$ & $4 \cdot 01$ & $2 \cdot 49$ & $141 \cdot 7$ & $23 \cdot 4$ & $49^{\circ} \circ$ & $69 \cdot 3$ \\
\hline 3 & 9.54 & $4 \cdot 84$ & 3.29 & I 70.9 & $23 * 3$ & $59 \cdot 0$ & $88 \cdot 6$ \\
\hline 4 & 13.30 & $6 \cdot 10$ & $4 \cdot 20$ & $215 \cdot 4$ & $27 \cdot 1$ & $86 \cdot 7$ & $101 \cdot 6$ \\
\hline 5 & 17.62 & 7.90 & $4 \cdot 58$ & $278 \cdot 7$ & $33 \cdot 5$ & I 5.9 & $129 \cdot 3$ \\
\hline 6 & $22 \cdot 45$ & $10 \cdot 10$ & $5 \cdot 24$ & $356 \cdot 5$ & $38 \cdot 1$ & 195.2 & $123: 2$ \\
\hline 7 & $27 \cdot 43$ & $1 \mathrm{I} \cdot 5^{8}$ & 4.53 & $408 \cdot 7$ & $49^{\circ} I$ & $240 \cdot 2$ & $119^{\circ} 4$ \\
\hline 8 & $33 \cdot 42$ & I 3.44 & $7 \cdot 10$ & 475.0 & $54: 3$ & $287 \cdot 0$ & $133 \cdot 7$ \\
\hline \multicolumn{8}{|c|}{ Pig $15 \mathrm{D}$} \\
\hline I & 4.24 & $3 \cdot 31$ & $2 \cdot 15$ & I $14 \cdot 6$ & $29 \cdot 1$ & $2 \mathrm{I} \cdot 8$ & $63 \cdot 7$ \\
\hline 2 & $6 \cdot 80$ & $4 \cdot 44$ & $2 \cdot 95$ & I 53.4 & $3 I \cdot I$ & $50 \cdot 7$ & $71 \cdot 6$ \\
\hline 3 & $9 \cdot 68$ & $5 \cdot 74$ & $2 \cdot 95$ & I 98.6 & $22 \cdot 8$ & $83 \cdot 0$ & $92 \cdot 8$ \\
\hline 4 & $\mathbf{1 2} \cdot 86$ & $7 \cdot 63$ & 3.29 & $263 \times 7$ & $32 \cdot I$ & $127 \cdot 7$ & 103.9 \\
\hline 5 & $16 \cdot 19$ & 10.15 & $3 \cdot 85$ & $35 I^{\circ} \circ$ & 39.0 & $I 62 \cdot I$ & $149^{\circ} 9$ \\
\hline 6 & $20 \cdot 30$ & $11 \cdot 30$ & 3.97 & $390 \cdot 7$ & $3^{8 \cdot 1}$ & $219 \cdot 2$ & 133.4 \\
\hline $\begin{array}{l}7 \\
8\end{array}$ & $24 \cdot 10$ & I I.67 & 3.52 & $403 \cdot 6$ & $39 \cdot 9$ & $219 \cdot 6$ & 144.1 \\
\hline & $28 \cdot 12$ & 13.08 & 4.99 & $452 \cdot 2$ & $47 \cdot 4$ & 312 & \\
\hline
\end{tabular}

Pig $20 \mathrm{~A}$

Pigs at $20^{\circ}$

\begin{tabular}{|c|c|c|c|c|c|c|c|}
\hline I & $5 \cdot 71$ & 3.01 & 3.17 & $115^{\circ} 7$ & $24 \cdot 7$ & $30 \cdot 2$ & $60 \cdot 8$ \\
\hline 2 & $9^{\circ}$ I I & $4 \cdot 6 I$ & $3 \cdot 63$ & $177^{\circ} \circ$ & $33^{\circ} 0$ & $51 \cdot 2$ & \\
\hline 3 & 14.03 & 8.06 & 4.99 & $309 \cdot 2$ & $42 \cdot 3$ & I 9.7 & $\mathbf{I}$ \\
\hline 4 & $17 \cdot 89$ & $6 \cdot 48$ & 4.08 & $248 \cdot 5$ & 354 & $127^{\circ} 0$ & \\
\hline 5 & $23 \cdot 51$ & 10.92 & 6.58 & $38_{5} \cdot 5$ & $44^{\prime 2}$ & 200.9 & \\
\hline 6 & $28 \cdot 62$ & $9 \cdot 68$ & $5 \cdot 45$ & $341 \cdot 7$ & $37 \cdot 5$ & I $9 \mathrm{I} \cdot 3$ & ד \\
\hline 7 & 35.09 & 1 3.98 & $4^{\circ} 99$ & 493.4 & $56 \cdot 7$ & $289 \cdot 0$ & I \\
\hline 8 & $4 I \cdot 08$ & 13.44 & $7 \cdot 30$ & 474.4 & $52 \cdot 5$ & 290.5 & I3I \\
\hline
\end{tabular}




\begin{tabular}{|c|c|c|c|c|c|c|}
\hline & Mean & $\begin{array}{l}\text { Food con- } \\
\text { sumption } \\
\text { (kg/week) }\end{array}$ & $\begin{array}{l}\text { Weight } \\
\text { gain } \\
(\mathrm{kg} / \text { week })\end{array}$ & $\begin{array}{c}\mathbf{N} \\
\text { intake } \\
\text { (g/week) }\end{array}$ & $\begin{array}{l}\text { Faecal } \\
\mathrm{N} \\
\text { (g/week) }\end{array}$ & $\begin{array}{l}\text { Urinary } \\
\mathrm{N} \\
\text { (g/week) }\end{array}$ \\
\hline
\end{tabular}

Pig 2oB

\begin{tabular}{|c|c|c|c|c|c|c|c|}
\hline I & $6 \cdot 63$ & $3 \cdot 56$ & $3 \cdot 06$ & $136 \cdot 8$ & $22 \cdot 7$ & $4 \mathrm{I} \cdot \mathrm{I}$ & 73.0 \\
\hline 2 & 10.09 & $5 \cdot 46$ & $4 \cdot 31$ & $209 \cdot 8$ & $28 \cdot 8$ & $78 \cdot 0$ & 103.0 \\
\hline 3 & $I 4.5 I$ & $6 \cdot 94$ & $4 \cdot 42$ & $245^{\circ} 0$ & $32 \cdot 8$ & 100.9 & I I I $\cdot 3$ \\
\hline 4 & $19 \cdot 15$ & $8 \cdot 65$ & $4 \cdot 99$ & 305.4 & $33 \cdot 8$ & $156 \cdot 4$ & I I $5^{\circ 2}$ \\
\hline 5 & 24.40 & 10.41 & $5 \cdot 33$ & $3^{67 \cdot 5}$ & $44 \cdot I$ & 203.5 & $1 \times 9.9$ \\
\hline 6 & $30.2 x$ & $12 \cdot 21$ & $5 \cdot 90$ & $43^{\circ} \cdot 9$ & $53 \cdot 7$ & 254.5 & $122 \cdot 7$ \\
\hline 7 & $35 \cdot 9 \mathrm{I}$ & $12 \cdot 74$ & $6 \cdot 10$ & $449 \cdot 6$ & 50.7 & $275^{\circ} 0$ & $123^{\circ} 9$ \\
\hline 8 & $4 I \cdot 1 I$ & $13 \cdot 19$ & $4 \cdot 50$ & $465 \cdot 6$ & 50.5 & $282 \cdot 8$ & $132 \cdot 3$ \\
\hline \multicolumn{8}{|c|}{ Pig $20 \mathrm{C}$} \\
\hline$I$ & $4 \cdot 75$ & $3 \cdot 35$ & $2 \cdot 84$ & I 20.4 & $28 \cdot 6$ & $25 \cdot 5$ & $66 \cdot 3$ \\
\hline 2 & $7 \cdot 82$ & $5 \cdot 13$ & $3 \cdot 17$ & $184^{\prime} I$ & $44^{\circ} 6$ & $54 \cdot 6$ & 84.9 \\
\hline 3 & I I'4I & $6 \cdot 31$ & 3.97 & $226 \cdot 7$ & $34 \cdot 8$ & 943 & $97 \cdot 6$ \\
\hline 4 & I5. IO & $6 \cdot 97$ & $3 \cdot 86$ & 250.2 & $30 \cdot 8$ & $123 \cdot 8$ & $95 \cdot 6$ \\
\hline 5 & I8. 19 & $7 \cdot 54$ & $4 \cdot 19$ & 270.8 & $32 \cdot 0$ & I $37 \cdot 8$ & YOI.O \\
\hline 6 & 23.53 & 9.28 & $4 \cdot 20$ & $333^{\prime}$ I & $4 I^{\prime} 5$ & $183^{-2}$ & $108 \cdot 4$ \\
\hline 7 & $28 \cdot 00$ & $9^{\cdot 93}$ & 4.53 & $35^{6} \cdot 3$ & $39^{\circ} 0$ & $208 \cdot 6$ & 108.7 \\
\hline 8 & $32 \cdot 79$ & $10 \cdot 32$ & $4 \cdot 65$ & $370 \cdot 5$ & $42 \cdot 7$ & $221 \cdot 7$ & $x 06 \cdot I$ \\
\hline \multicolumn{8}{|c|}{ ig $20 \mathrm{D}$} \\
\hline 1 & 4.11 & $2 \cdot 38$ & $2 \cdot 49$ & $85 \cdot 5$ & 16.9 & $21 \cdot 9$ & $46 \cdot 7$ \\
\hline 2 & $6 \cdot 69$ & $4 \cdot 26$ & 3.06 & 152.8 & $4 I \cdot 2$ & $37 \cdot 6$ & $74 \cdot 0$ \\
\hline 3 & 10.33 & $6 \cdot 08$ & $3 \cdot 97$ & $218 \cdot 2$ & 53.5 & $58 \cdot 5$ & $106 \cdot 2$ \\
\hline 4 & 14.97 & $7 \cdot 59$ & $4 \cdot 88$ & $272 \cdot 6$ & 40.9 & $117 \cdot 2$ & 114.5 \\
\hline 5 & 19.05 & $8 \cdot 17$ & 4.08 & 293.2 & $39^{\circ} 8$ & 140.0 & I 13.4 \\
\hline 6 & $24 \cdot 13$ & 10.22 & 5.67 & $366 \cdot 8$ & $46 \cdot 8$ & I 80.9 & I $39^{\circ} \mathrm{I}$ \\
\hline \multirow{2}{*}{$\begin{array}{l}7 \\
8\end{array}$} & 29.67 & II 87 & $5 \cdot 90$ & $426 \cdot I$ & $44 \cdot 6$ & $26 r \cdot 6$ & I 19.9 \\
\hline & $34 \cdot 84$ & I I'74 & $3 \cdot 96$ & $42 I \cdot 5$ & $45^{\cdot 2}$ & $263 \cdot 2$ & I I $3 \cdot 1$ \\
\hline
\end{tabular}

Pig $25 \mathrm{~A}$

Pigs at $25^{\circ}$

\begin{tabular}{|c|c|c|c|c|c|c|c|}
\hline I & $5 \cdot 28$ & $2 \cdot 56$ & $2 \cdot 89$ & $93 \cdot 8$ & $20 \cdot I$ & r9.5 & $54 \cdot 2$ \\
\hline 2 & $8 \cdot 67$ & $4 \cdot 85$ & $3 \cdot 97$ & $177 \cdot 5$ & 25.0 & $42 \cdot 7$ & 109.8 \\
\hline 3 & $12 \cdot 84$ & $6 \cdot 55$ & $4 \cdot 20$ & $239^{-8}$ & $33 \cdot 8$ & 59.5 & $146 \cdot 5$ \\
\hline 4 & $17 \cdot 12$ & $7 \cdot 66$ & $4 \cdot 42$ & 280.0 & $33 \cdot 6$ & 1354 & I I I : O \\
\hline 5 & $2 I \cdot 39$ & $8 \cdot 17$ & $4 \cdot 20$ & $299^{\circ} I$ & $27 \cdot 8$ & $162 \cdot 5$ & $108 \cdot 8$ \\
\hline 6 & $26 \cdot 11$ & 10.15 & $5 \cdot 33$ & $371 \cdot 3$ & $47^{\cdot 6}$ & 216.8 & 106.9 \\
\hline 7 & $3 x \cdot 24$ & IX'I 5 & $5 \cdot 10$ & $408 \cdot 2$ & $42 \cdot 3$ & $152 \cdot 0(?)$ & 213.9 (?) \\
\hline 8 & $36 \cdot 77$ & $12 \cdot 00$ & 4.99 & $439^{\circ} \mathrm{I}$ & $56 \cdot 2$ & $194^{\circ} \circ(?)$ & I88.9(?) \\
\hline \multicolumn{8}{|c|}{ Pig $25 \mathrm{~B}$} \\
\hline I & $4 \cdot 82$ & $2 \cdot 37$ & $2 \cdot 49$ & $83 \cdot 6$ & 14.3 & $20 \cdot 5$ & $48 \cdot 9$ \\
\hline 2 & $7 \cdot 32$ & 3.54 & $2 \cdot 95$ & 124.9 & $26 \cdot 8$ & $36 \cdot 5$ & $6 I \cdot 6$ \\
\hline 3 & 10.56 & $4^{-65}$ & $3 \cdot 40$ & 164.0 & $37 \cdot 9$ & $48 \cdot 8$ & $77 \cdot 3$ \\
\hline 4 & 15.03 & $9^{\circ} 19$ & $4 \cdot 19$ & $324 \cdot 0$ & $44^{\circ} 0$ & $175 \cdot 2$ & $\mathrm{IO}_{4} \cdot 8$ \\
\hline 5 & $17 \cdot 35$ & 10.20 & $5 \cdot 34$ & $3^{62} \cdot 0$ & $42 \cdot 4$ & 203.8 & I 15.8 \\
\hline 6 & $24 \cdot 77$ & II'IO & $5 \cdot 67$ & $398 \cdot 4$ & $34^{\circ} 7$ & $25^{8} \cdot 7$ & 105.0 \\
\hline 7 & 30.29 & 10.96 & $5 \cdot 67$ & $393 \cdot 6$ & $36 \cdot 2$ & $245 \cdot 3$ & I I2:I \\
\hline 8 & $36 \cdot 12$ & $12 \cdot 96$ & $4 \cdot 65$ & $465 \cdot 2$ & 39.2 & $289^{\circ} I$ & $136 \cdot 9$ \\
\hline \multicolumn{8}{|c|}{ Pig ${ }_{25} \mathrm{C}$} \\
\hline I & $5 \cdot 49$ & $2 \cdot 84$ & $2 \cdot 83$ & 100.0 & I9. I & $23 \% 4$ & $57 \cdot 5$ \\
\hline 2 & 8.87 & $4 \cdot 73$ & 3.74 & 166.9 & $27 \cdot 4$ & $52 \cdot 9$ & 86.6 \\
\hline 3 & 12.87 & 6.40 & 3.98 & $229^{\circ} 8$ & 30.1 & 79.5 & 120.2 \\
\hline 4 & 17.45 & $7 \cdot 67$ & $4 \cdot 98$ & $275^{\prime 2}$ & 27.9 & $123 \cdot I$ & $124 \cdot 2$ \\
\hline 5 & $22 \cdot 24$ & $8 \cdot 25$ & 4.99 & $296 \cdot I$ & $28 \cdot 8$ & $139 \cdot 3$ & $128 \cdot 1$ \\
\hline 6 & $27 \cdot 83$ & 10.29 & $5 \cdot 67$ & 369.4 & 38.7 & $201 \cdot 8$ & $128 \cdot 9$ \\
\hline 7 & 33.01 & $10.8 \mathrm{I}$ & 5.22 & $3^{88.2}$ & $37 \cdot 6$ & $229^{\circ} 0$ & $121 \cdot 6$ \\
\hline 8 & $37 \cdot 95$ & I I 43 & $4 \cdot 76$ & $410 \cdot 1$ & $37 \cdot 9$ & 253.3 & I 18.9 \\
\hline
\end{tabular}


Mean Food con- Weight $N$ Faecal Urinary $N$

body-weight sumption gain intake $N \quad N$ balance

Week (kg) (kg/week) (kg/week) (g/week) (g/week) (g/week) (g/week)

\begin{tabular}{|c|c|c|c|c|c|c|c|}
\hline ig & & & & & & & \\
\hline I & $6 \cdot 46$ & 3.57 & $3 \cdot 28$ & I $28 \cdot 3$ & $28 \cdot 7$ & 29.9 & 69.7 \\
\hline 2 & $9 \cdot 99$ & 4.97 & 3.52 & $\mathrm{r} 78 \cdot 5$ & 29.4 & $56 \cdot 1$ & $93{ }^{\circ}$ \\
\hline 3 & 14.23 & 7.52 & 4.99 & $270^{\circ} 0$ & $35^{\prime 2}$ & IOZ'3 & 132.5 \\
\hline 4 & 19.24 & $9 \cdot 30$ & $5 \cdot 33$ & 333.8 & $36 \cdot 5$ & $183 \cdot 0$ & II 43 \\
\hline 5 & 24.89 & $10 \cdot 76$ & 5.44 & $386 \cdot 2$ & $36 \cdot 2$ & $232: 4$ & $\operatorname{II} 7 \cdot 6$ \\
\hline 6 & $30 \cdot 42$ & $12 \cdot 06$ & $6 \cdot 01$ & $4 I 7 \cdot 1$ & $4 I \cdot I$ & $287 \cdot 1$ & $88 \cdot 9$ \\
\hline 7 & $36 \cdot 70$ & 13.52 & $6 \cdot 58$ & $467 \cdot 5$ & $38 \cdot 8$ & $284 \cdot 3$ & I 44.3 \\
\hline 8 & $42 \cdot 01$ & 14.67 & $4 \cdot 47$ & 507.3 & 44.9 & $348 \cdot 7$ & I 137 \\
\hline
\end{tabular}

Pig 30A

Pigs at $30^{\circ}$

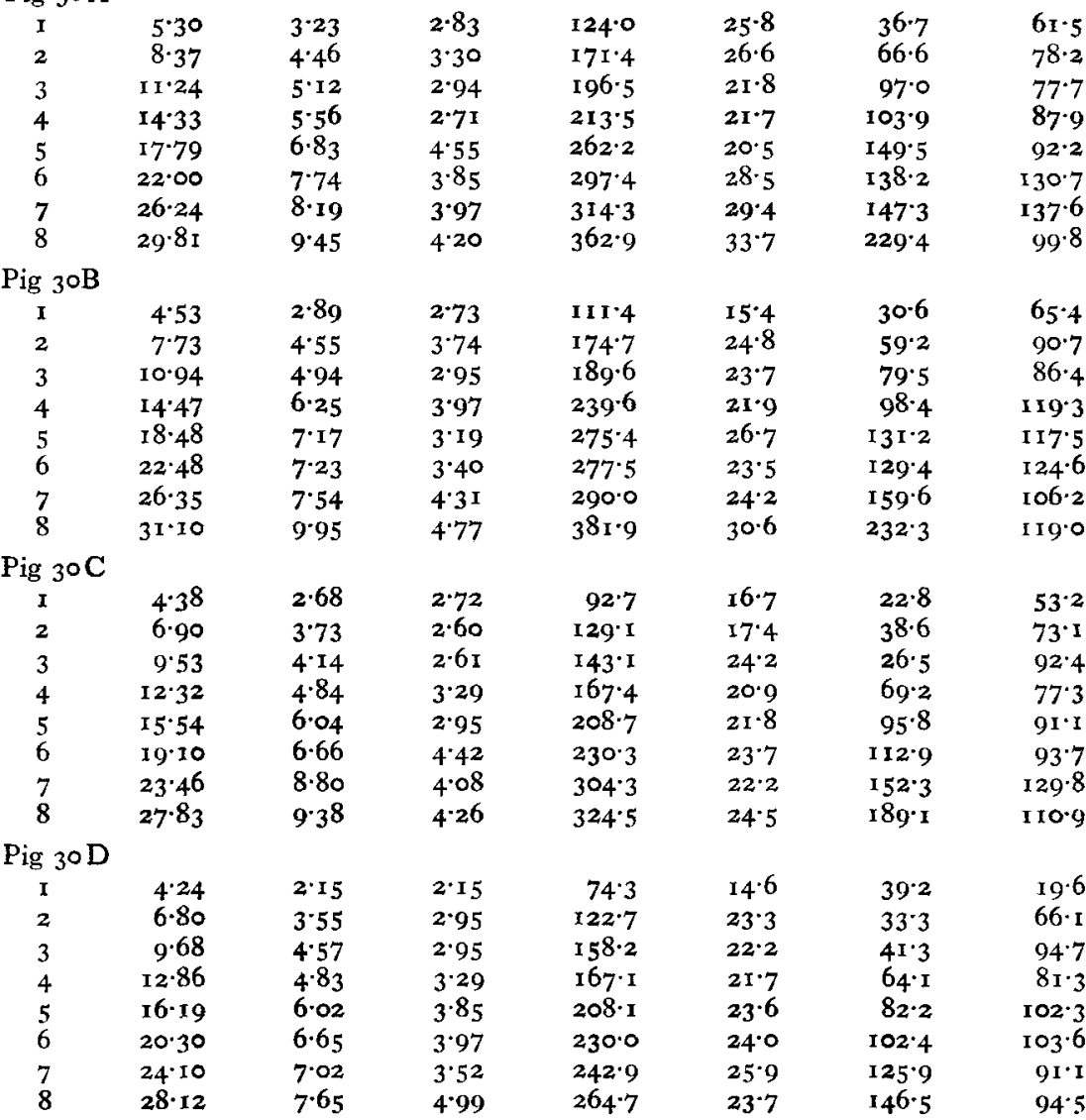

